\title{
Environmental legislation and variable communicative and pedagogical competence formation model for employees of penal system
}

\author{
Michael Lebedev ${ }^{1, *}$ \\ ${ }^{1}$ Research Institute of Federal Penitentiary Service of Russia, Narvskaya str., 15 a, building 1, \\ Moscow, 125130, Russian Federation
}

\begin{abstract}
The article describes the issue of formation of communicative and pedagogical competence among employees of penal system. The proposed method of using the means of professional mentoring is stipulated as a social order for training of specialists of penal system in the process of carrying out practical activities in an institution executing criminal sentences or in a pretrial detention center.
\end{abstract}

\section{Introduction}

The relevance of the scientific article can be explained by the increasingly complex tasks facing the penal system of Russia, modification of criminal offenses, lack of psychological and pedagogical knowledge and skills among employees performing pedagogical functions in relation to persons serving sentences and other employees. A factorial role in solving these problems belongs to educational work with employees by means of professional mentoring as the leading mechanism for implementation of tasks of state personnel policy.

The strategies of this stage of development of penitentiary system in the context of transition of Russian society from an industrial formation to an informational one are aimed at providing the penitentiary system with new qualified personnel with innovative communication competence in the context of pedagogical process. This is due to the transformation factor of a number of crimes, complication of their specificity, grave and especially grave crimes, and their recurrence. These circumstances highlight the task of developing communicative and pedagogical competencies among employees by means of professional mentoring as a special institution of vocational training, without interrupting service, in real time. This type of professional training is designed to ensure practical mastery of psychological and pedagogical methods of constructing the most diverse types of relationships that may arise in the penitentiary system.

*Corresponding author: kornei_lam@mail.ru 


\section{Methods}

Development of the issue outlined in a scientific article involves the analysis of scientific pedagogical literature, which we conditionally divided into four groups.

The first group includes works devoted to scientific development of fundamental foundations of penitentiary education (A.G. Goldenveiser, A.F. Koni, S.P. Mokrinsky, V.S. Soloviev, I.Ya. Foinitsky, etc.).

The second group includes works devoted to the issue of forming communicative abilities of employees, improving professionalism by means of educational work using verbal and non-verbal communication tools in an extreme environment, including penitentiary institutions (G.A. Avanesov, I.T. Bogatyrev, D. V. Voloshin, T. V. Volkova, O.S. Gazman, O. V. Gutsev, V. G. Igoshin, A. M. Kiselev, V. I. Lebedev, V. M. Litvishkov, A. V. Mitkina, V.I. Ogorodnikov, Yu.F. Podlepnyak, S.K. Redkov, O.V. Svinareva, A.N. Sukhov, I.V. Ulyanova and others).

The third group includes works exploring psychological patterns of reeducation, motivational mechanisms of communication that determine the foundations of pedagogical interaction (F.B. Berezin, W. James, G. Laswell, A.N. Leontiev, A.S. Makarenko, T. Parsons, R. Frankin and others); works devoted to the identification of psychodynamic aspects of formation of professionalism; personal, moral, legal, pedagogical potential of the staff of penal system (S.A. Abasova, A.T. Ivanitskiy, D.V. Sochivko, E.A.Timofeeva, N.A.Tyugaeva, N.N. Tavtilova, B.M. Teplov, E.F. Usmanova, I.V. Khamidova and others).

The fourth group is represented by scientific works, which contain a statement of problem of professional mentoring in the penal system of Russia, substantiates its potential as a means of professional competence, a mechanism for increasing the professionalism of employees (S.M. Nurbaev, A.N.Sapozhnikov, Yu.M. Chuikov, etc.).

The research methodology consisted of:

- theoretical methods: analysis of scientific-theoretical, educational, methodological, statistical, encyclopedic literature, retrospective analysis of scientific works, analysis of regulatory legal acts, official reports, curricula, professional retraining programs, advanced training in educational institutions; systematization, generalization, synthesis, modeling, design;

- empirical methods: questioning, testing, observation, conversation, interview, pedagogical experiment;

- Methods of mathematical statistics: scaling, ranking, using the SPSSv 13.0. program and Student's test.

\section{Results}

As a result of the study, it was determined that communicative and pedagogical competence of employees of penitentiary system is a category of penitentiary pedagogy, denoting generative ability of a person to reproduce communicative knowledge, skills and abilities of goal setting, selection of methods, mechanisms for constructing relationships in conditions of extreme penitentiary environment. The content of communicative and pedagogical competence includes a system of scientific knowledge about the analysis of delinquent behavior; communication mechanisms (verbal / non-verbal, motivational) that provide the processes of perception, analysis, processing, transmission of information, divergence of feedback channels. The structure of communicative and pedagogical competence of specialists is formed by a set of personal and professional clusters of competencies: personal, reflexive, operational, activity.

Also, in the course of the study, it was revealed that the activity of professional mentoring is a means of forming the communicative and pedagogical competence of 
employees of penal system. Professional mentoring is an integral, practice-oriented part of an integral system of professional training at the level of professional training and education of employees.

The main means of professional mentoring in the formation of communicative and pedagogical competence of employees are: scientific and methodological support, vocational training, educational work, pedagogical support, motivating professional development, training of pedagogical communications.

The variable model of formation of communicative and pedagogical competence among employees by means of professional mentoring in the conditions of institutions of penal system of Russia is a combination of personnel, scientific and methodological, criterion and diagnostic components. Pedagogical conditions of process of forming communicative and pedagogical competence are:

1) a variable model of formation of professional and communicative competence of employees on the basis of a correctional institution without interruption from service;

2) educational clusters of communicative and pedagogical competencies as a standard of communicative and pedagogical competence of an employee;

3) the use of innovative educational technologies.

In order to identify the significance in differences in the indicators of formation of levels of competence obtained from the respondents of control and experimental groups, and to prove the effectiveness of proposed variable model, the Student's t-test was used.

It should be noted that we have identified interrelated areas of activity of a specialistmentor, namely, diagnostic, design, organizational activity, monitoring of dynamics of educational process.

A detailed analysis of results of implementation of variable model of professional and communicative competence formation is presented in Table 1.

Table 1. Indicators of formation of levels of communicative and pedagogical competence.

\begin{tabular}{|c|c|c|c|c|c|c|}
\hline \multirow{3}{*}{ Component } & \multicolumn{6}{|c|}{ Component formation level (mean value) } \\
\hline & \multicolumn{2}{|c|}{ Low level } & \multicolumn{2}{|c|}{ Average level } & \multicolumn{2}{|c|}{ High level } \\
\hline & $\begin{array}{l}\text { Control } \\
\text { group }\end{array}$ & $\begin{array}{l}\text { Expert } \\
\text { group }\end{array}$ & $\begin{array}{l}\text { Control } \\
\text { group }\end{array}$ & $\begin{array}{l}\text { Expert } \\
\text { group }\end{array}$ & $\begin{array}{c}\text { Control } \\
\text { group }\end{array}$ & $\begin{array}{l}\text { Expert } \\
\text { group }\end{array}$ \\
\hline $\begin{array}{l}\text { Moral and } \\
\text { volitional } \\
\text { component }\end{array}$ & 3 & 1 & 6 & 4 & 15 & 21 \\
\hline $\begin{array}{l}\text { Communicative } \\
\text { and pedagogical } \\
\text { education of a } \\
\text { trainee }\end{array}$ & 3 & 0 & 4 & 3 & 19 & 23 \\
\hline $\begin{array}{l}\text { Trainee's } \\
\text { pedagogical } \\
\text { communication } \\
\text { skills }\end{array}$ & 3 & 1 & 5 & 2 & 16 & 22 \\
\hline $\begin{array}{l}\text { Information and } \\
\text { communication } \\
\text { component }\end{array}$ & 3 & 1 & 6 & 3 & 16 & 21 \\
\hline $\begin{array}{l}\text { Reflective } \\
\text { component }\end{array}$ & 3 & 1 & 7 & 4 & 15 & 20 \\
\hline $\begin{array}{l}\text { Student's t-test at } \\
\mathrm{p} \leq 0.05\end{array}$ & $\begin{array}{l}\text { t emp }=1 \\
\text { (zone } \\
\text { significan }\end{array}$ & e) & $\begin{array}{l}\text { t emp }=3 \\
\text { (zone of }\end{array}$ & nificance) & $\begin{array}{l}\mathrm{t} \text { emp }=5.8 \\
\text { (zone of siq }\end{array}$ & cance) \\
\hline
\end{tabular}




\section{Discussion}

In order to disclose the topic of the scientific article, I analyzed the current state of institution of professional mentoring in the penal system of Russia, after which I concluded that there is a lack of new educational programs, scientific and practical recommendations that would reflect the existing reality and specifics of this area of activity in the penal system.

According to the results of the survey, it was revealed the most common methods of working with young employees proposed in the regulatory documents are: personal example of a mentor - $75 \%$, educational conversations - $68 \%$, study of employee's personality and control over employee activities - 58\%, individual assistance - $50 \%$, studying the personality of an employee $-47 \%$, individual tasks and assignments $-28 \%$, consulting - $27 \%$, out-of-office communication - $25 \%$. The respondents believe that the most effective methods are: personal example of a mentor - $71 \%$, educational conversations - $64 \%$, individual assistance - 51\%, studying the personality of an employee - $40 \%$, counseling - $37 \%$, control over employee activities - $32 \%$.

The results of the work carried out to determine the real state of mentoring indicate that over $86 \%$ of mentors need periodic consultations on various issues, both of a service and pedagogical nature. Our study of practical activities of mentors shows that experienced mentors $(44 \%)$ often experience difficulties in defining the competencies inherent in a professional mentor, they cannot always choose the optimal tools for mentoring, choose a model for transferring their experience. Employees who become mentors for the first time (26\%) also need support of more experienced colleagues in organizing planned pedagogical and psychological work of an individual nature. A considerable part of mentors surveyed $(30 \%)$ stated that this activity is formal, and there are no additional payments for its implementation.

At the center of research was the issue of ensuring the effectiveness of process of forming communicative and pedagogical competence by means of mentoring, solution of which empirically will allow to resolve the contradiction between the needs of penal system in highly qualified personnel with communicative and pedagogical competence in matters of education, correction, adaptation, resocialization of convicts and the lack of scientific and methodological support of mentoring as a means of vocational training and education of personnel.

In general, the survey, conversations, interviews made it possible to cover significant segments of empirical objects in which real processes of interaction with convicts, communication, and their upbringing take place. Due to the quantitative specifics of interviews undertaken, it was possible to identify narrow and problematic aspects of practice of interaction between employees and convicts, to include these questions in the content of experiment and, upon its completion, to optimize the variable model of formation of communicative and pedagogical competence of employees.

Along with this, during the experimental activity, psychological and pedagogical research methods were used.

About $84 \%$ of employees indicate that pedagogical competence is a problem for services related to educational functions. In particular, in the course of interviews, the chiefs of detachments note that they have a diploma of higher education, but this education is not pedagogical. During the interviews, they pointed out the lack of theoretical and practical knowledge in the field of communicative and pedagogical competence in a penitentiary institution.

In the course of answers, a problematic situation was revealed in relation to the communicative and pedagogical competence on the part of employees themselves, as evidenced by the data obtained. More than a third of respondents $(36.8 \%)$ noted the lack of 
demand in penitentiary practice for communicative and pedagogical competence of a correctional institution employee, skills and abilities to competently build pedagogical interaction with convicts. Along with this, $44.4 \%$ of respondents note their dissatisfaction with the existing level of communicative knowledge in the field of penitentiary pedagogy. More than half $(58.0 \%)$ of employees consider the work of the institute of mentoring in institutions for professional training of employees on the job as ineffective, i.e. not meeting modern requirements. Such dissatisfaction and ineffectiveness is convincingly confirmed by the fact that the respondents experience significant difficulties in pedagogical communications, with definition of typology of convicts, their characteristics, nature of problems of interaction, education, correction. In most cases, employees do not know any techniques of verbal, non-verbal, paraverbal pedagogical communication

A survey of 21 mentors was conducted on a separate questionnaire, which showed the problematic state of mentoring, the presence of formalism, the lack of necessary scientific and methodological tools (training and education programs for trainees, correct individual training plans for employees; educational technologies for formation of communicative competence, etc.). The survey showed the need to train mentors to participate in the experiment in order to effectively train the trainees.

In order to identify dynamics of trainees of experimental group (25 people) and employees (30 people) of control group, a knowledge survey was conducted through the final test. Thus, the control group is inferior to the respondents in the experimental group in all positions. The results of knowledge of control group in terms of questions: essence, characteristics of a complex of pedagogical conditions - are in the range from $36.7 \%$ to $63.3 \%$. The level of knowledge of experimental group in the relevant parameters is in the range from $72.0 \%$ to $84.0 \%$.

A survey of employees showed that the level of knowledge of control group is almost $30 \%$ lower than for the same measured parameters in experimental group.

Thus, the obtained results of final stage of the experiment demonstrated a high level of communicative and pedagogical competence of trainees, mentors (experimental group). Thus, the employees of this group at the initial stage assessed their communicative and pedagogical skills at 5.0 points, while at the final stage the level of correct answers to the control test was: trainees - at the level of $75.7 \%$; mentors $-80.5 \%$. Based on the results of the experiment, the experts evaluated the levels of trainees.

\section{Conclusion}

To summarize, the article defines essential characteristics of communicative and pedagogical competence of employees of penal system. The central concept of the research is the communicative and pedagogical competence of a penal system employee, which denotes the integrative characteristic of ability to adaptively reproduce communicative knowledge, skills, goal-setting skills, selection of methods for constructing types of interaction with convicts and persons held in custody in the extreme environment of penitentiary institutions.

In the context of reforming the penal system, requirements for the level of professional competence of employees are increasing. An employee is called to be a professional with the necessary knowledge, skills, work experience, competence of communicative and pedagogical communication, which directly affects the quality of performance of official duties in accordance with the position held. 


\section{Acknowledgments}

The author expresses deep gratitude to the leadership of Federal State Institution of Scientific Research Institute of Federal Penitentiary Service of Russia for help and support provided during this study.

\section{References}

1. M.V. Lebedev, Human capital 5(77), 143-145 (2015)

2. T.M. Newcomb, Psychol. Rew. 60, 293-304 (1953)

3. T. Parsons, The social system (The free press, N.Y., 1964 (1951))

4. P. Zimbardo, Pathology of imprisonment. Society (1972)

5. I.V. Ulyanova, Pedagogy of life-meaning orientations (UMO stamp): textbook (Vladimir, 2010)

6. N.B. Kutakov, I. V Karavaev, I.E. Tretyakov, R.Z. Useev, Regime requirements in colonies-settlements of enhanced surveillance: guidelines (Academy of Federal Penitentiary Service of Russia, Ryazan, 2011)

7. The program of psychological and pedagogical influence on convicts who are carriers of religious extremist beliefs: a methodological guide (VIPE FSIN of Russia, Vologda, 2014)

8. D.Ya. Raigorodsky, Practical psychodiagnostics: Methods and tests: textbook (Publishing House "BAHRAKH", Samara, 2007)

9. E.A. Yunusov, S.M. Vorobiev, A.G. Akhverdyan, A.G. Grunin, R.D. Khritin, Dilemas contemporáneos: Educación, Política y Valores 7(S10), 83 (2019)

10. V.F. Lapshin, S.A. Korneev, E3S Web of Conferences 135, 04063 (2019) DOI: 10.1051 / e3sconf / 201913504063

11. A.A. Brovkina, V.E. Vezlomtsev, S.S. Zakharova, O.A. Shuranova, Yu.V. Truntsevsky, E3S Web of Conferences 135, 04066 (2019) DOI:10.1051

12. A.V. Kopytova, N.S. Zotkina, I.G. Reshetnikova, MATEC Web of Conferences 239, 04012 (2018) DOI: 10.1051/matecconf/201823904012

13. V. Lez'Er, N. Semeryanova, A. Kopytova, I. Kvach, E3S Web of Conferences 110, 02094 (2019) DOI: 10.1051/e3sconf/201911002094

14. R. Kolobov, U. Filatova, V. Borshcheniuk, N. Semerianova, D. Bayanov, E3S Web of Conferences 110, 02095 (2019) DOI: 10.1051/e3sconf/201911002095

15. Y.V. Truntsevsky, I.I. Lukiny, A.V. Sumachev, A.V. Kopytova, MATEC Web of Conferences 170, 01067 (2018) DOI: 10.1051/matecconf/201817001067 